Instituto Internacional de Investigación y Desarrollo Tecnológico Educativo INDTEC, C.A.

DOI: https://doi.org/10.29394/Scientific.issn.2542-2987.2021.6.22.0.10-19

OAI-PMH: http://www.indteca.com/ojs/index.php/Revista Scientific/oai

\title{
Las Estrategias Didácticas y su Incidencia en los Ambientes de Aprendizaje
}

\author{
PhD. Oscar Antonio Martínez Molina \\ Universidad Nacional de Educación, UNAE \\ oscar.martinez@unae.edu.ec \\ Azogues, Ecuador \\ https://orcid.org/0000-0003-1123-5553
}

\section{Editorial}

La situación de pandemia que vivimos desde marzo del año 2020 vuelve a ser vigente y más fuerza en la actualidad. Esta situación ha obligado que se implementes nuevas estrategias, en el que el juego cumple un papel importante. Según Duarte (2003):

El juego es una función vital sobre la que no es posible aún dar una definición exacta en términos lógicos, biológicos 0 estéticos. Descrito por sus características, el juego no es "vida corriente" ni "vida real", sino que hace posible una evasión de la realidad a una esfera temporal, donde se llevan a cabo actividades con orientación propia (pág. 14).

Acorde con lo anterior, es necesario que el estudiante identifique y sobresalga dentro de su contexto, el sujeto de estudio en este caso será el alumno, siempre deberá tener una motivación dentro de los ambientes.

En el marco teórico de este apartado, la National Assciation for the Education of Young Children (NAEYC); Bredekamp (1987), citados por Meece (2001): "recomienda que los programas destinados a los niños que empiezan a caminar y a los preescolares incluyan actividades en el interior y en el exterior para que ejerciten los músculos grandes" (pág. 74); de tal manera que se logre que los niños participen, en este mismo orden de ideas, Loyo y Toaquiza (2016), coinciden al afirmar que:

La acción de jugar es auto motivada de acuerdo con los intereses personales o impulsos expresivos. El juego natural tolera todo el rango de habilidades de movimiento, las normas o reglas son autodefinidas, la actividad es espontánea e 
individual. Es en parte un reflejo del entorno que rodea al individuo [...] (pág. 27).

En este sentido Flinchum (1998), citado por Nanfro (2016): nos habla de que "el juego abastece al niño de libertad para liberar la energía que tiene reprimida, fomenta las habilidades interpersonales y le ayuda a encontrar un lugar en el mundo social" (pág. 11); se plantea y resuelve problemas propios de la edad. Ambientes de aprendizaje o Ambiente educativo.

\section{Algunas Estrategias didácticas de aprender a reaprender}

El juego, Experimentación, Observación, Lenguaje oral y escrito (trabajo con textos) y Resolución de problemas, son consideradas estrategias fundamentales en el proceso enseñanza aprendizaje. En este sentido, Meneses y Monge (2001), en su libro El juego en los niños: enfoque teórico, señala que explicar que de manera natural los niños exploran su entorno inmediato y experimentan con los objetos a su alcance. Resulta fundamental generar oportunidades para que los niños formulen preguntas, anticipen lo que puede ocurrir y argumenten sus ideas, resuelvan problemas y compartan los resultados.

\section{La Experimentación (Primera fase del juego)}

Mencionando a Cardona (2004), esta situación así planteada, nos permite desde el modelo pedagógico ir precisado la motivación hacia la experimentación de aprender a través del juego:

Además, es necesario tener en cuenta cinco aspectos esenciales para considerar qué tipo de estrategia es la indicada para utilizarse en cierto momento de la enseñanza, dentro de una sesión, un episodio o una secuencia instruccional, a saber: Consideración de las características generales de los aprendices (nivel de desarrollo cognitivo, conocimientos previos, factores, motivaciones, entre otros); Tipo de dominio del conocimiento en general y del contenido curricular en particular, que se va a abordar; La 
intencionalidad o meta que se desea lograr y las actividades cognitivas y pedagógicas que debe realizar el alumno para conseguirla; Vigilancia constante del proceso de enseñanza (de las estrategias de enseñanza empleadas previamente, si es el caso), así como del progreso y aprendizaje de los alumnos; Determinación del contexto intersubjetivo (por ejemplo, el conocimiento ya compartido) creado con los alumnos hasta ese momento si es el caso (págs. 73-74).

\section{El Ambiente de aprendizaje o el Ambiente educativo en el juego}

Para Paredes y Sanabria (2015): los ambientes educativos son todos aquellos espacios donde se construye un aprendizaje, interactuando docentes y alumnos, fomentando la comunicación y proyectando confianza y apoyo hacia los niños, motivando sus conductas positivas y logros alcanzados en cada intervención docente, apoyadas en el currículo.

Con base en las acciones llevadas a cabo con el alumnado, se identifica que, la problemática a desarrollar es principalmente generar ambientes de estudio que sean propicios para que los educandos adquieran aprendizajes significativos, además de fomentar la participación entusiasta y armónica entre los mismos, es por ello que se debe diseñar actividades tomando en cuenta las estrategias didácticas básicas: la observación, experimentación, expresión oral y escrita, el juego y resolución de problemas.

No basta con diseñar y aplicar actividades utilizando las estrategias mencionadas, es necesario trabajar desde un inicio el seguimiento de reglas, la motivación ante conductas positivas, cuestionar sobre los intereses de los alumnos y tomar acuerdos democráticos tomando en cuenta la opinión de todos los estudiantes. Además, para lograr un escenario afectivo es preciso demostrar amor, brindar confianza y ser compresiva ante toda situación que se presente, de esta manera los alumnos podrán visualizar a un amigo, un confidente y un apoyo.

Es importante autoevaluar la práctica docente para innovar la propia intervención y mejorar así la calidad de la educación que se brinda. Y una 
herramienta importante para ello es el uso del Internet, el cual abre puertas para la búsqueda de ideas y potencializar la creatividad de cada docente. Por todo ello, es importante después de cada intervención, valorarla y evaluarla para buscar alternativas de mejora, aunque las actividades hayan sido favorables hay posibilidad de mejorar o darle otro sentido para trabajar con una misma estrategia distintos campos formativos.

\section{Revisión teórica (resolución de problemas)}

Generar ambientes propicios para el aprendizaje haciendo uso de estrategias didácticas como experimentación, resolución de problemas, observación, el juego y expresión oral y escrita. Proporcionar a docentes de nivel preescolar actividades que ayuden a desarrollar en los alumnos competencias, conocimientos, valores y principios, así como habilidades y destrezas, generando en ellos aprendizajes significativos.

\section{Reflexión}

La evaluación como mejora de la intervención docente para la generación de ambientes de aprendizaje se propone la aplicación de estrategias didácticas para el nivel preescolar, dónde se propicie el desarrollo de competencias, conocimientos y habilidades que potencialicen el aprendizaje significativo en los alumnos. Se pretende proporcionar a las docentes de este nivel ideas para aplicar dichas estrategias en las actividades curriculares durante una mañana de trabajo en cualquier momento del ciclo escolar.

Palabras clave: estrategias didácticas; ambientes de aprendizaje; juego.

Fecha de Recepción: 05-08-2021
Fecha de Aceptación:

11-10-2021
Fecha de Publicación: 05-11-2021 
Instituto Internacional de Investigación y Desarrollo Tecnológico Educativo INDTEC, C.A.

DOI: https://doi.org/10.29394/Scientific.issn.2542-2987.2021.6.22.0.10-19

OAI-PMH: http://www.indteca.com/ojs/index.php/Revista Scientific/oai

\section{Teaching Strategies and their Impact on Learning Environments}

\section{Editorial}

The pandemic situation that we have experienced since March 2020 is

once again in force and is stronger today. This situation has forced you to implement new strategies, in which the game plays an important role. According to Duarte (2003):

Play is a vital function about which it is not yet possible to give an exact definition in logical, biological or aesthetic terms. Described by its characteristics, the game is not "ordinary life" or "real life", but rather makes possible an escape from reality to a temporal sphere, where activities with their own orientation are carried out (p. 14)

In accordance with the above, it is necessary for the student to identify and stand out within their context, the subject of study in this case will be the student, they must always have a motivation within the environments.

Within the theoretical framework of this section, the National Association for the Education of Young Children (NAEYC); Bredekamp (1987), cited by Meece (2001): "recommends that programs for toddlers and preschoolers include indoor and outdoor activities to exercise large muscles" (p. 74); in such a way that the children participate, in this same order of ideas, Loyo and Toaquiza (2016), coincide in stating that:

The action of playing is self-motivated according to personal interests or expressive impulses. Natural play tolerates the full range of movement skills, norms or rules are self-defined, activity is spontaneous and individual. It is partly a reflection of the environment that surrounds the individual [...] (p. 27).

In this sense, Flinchum (1998), cited by Nanfro (2016): tells us that "play provides the child with freedom to release the energy that he has repressed, fosters interpersonal skills and helps him find a place in the social world" (p. 11); poses and solves problems of age. Learning environments or Educational environment. 


\section{Some didactic strategies of learning to relearn}

The game, experimentation, observation, oral and written language (work with texts) and problem solving are considered fundamental strategies in the teaching-learning process. In this sense, Meneses and Monge (2001), in their book Play in Children: Theoretical Approach, points out that explaining that children naturally explore their immediate environment and experiment with the objects within their reach. It is essential to create opportunities for children to ask questions, anticipate what may happen and argue their ideas, solve problems and share the results.

\section{The Experimentation (First phase of the game)}

Mentioning Cardona (2004), this situation thus posed, allows us from the pedagogical model to specify the motivation towards the experimentation of learning through play:

In addition, it is necessary to take into account five essential aspects to consider what type of strategy is indicated to be used at a certain moment of teaching, within a session, an episode or an instructional sequence, namely: Consideration of the general characteristics of the learners (level of cognitive development, previous knowledge, factors, motivations, among others); Type of domain of knowledge in general and of the curricular content in particular, to be addressed; The intention or goal to be achieved and the cognitive and pedagogical activities that the student must carry out to achieve it; Constant monitoring of the teaching process (of the teaching strategies previously used, if applicable), as well as the progress and learning of the students; Determination of the intersubjective context (for example, the knowledge already shared) created with the students up to that point if this is the case (pp. 73-74).

\section{The learning environment or the educational environment in the game}

For Paredes and Sanabria (2015): educational environments are all those spaces where learning is built, with teachers and students interacting, promoting communication and projecting trust and support towards children, 
motivating their positive behaviors and achievements in each teaching intervention, supported by the curriculum.

Based on the actions carried out with the students, it is identified that the problem to be developed is mainly to generate study environments that are conducive for students to acquire meaningful learning, in addition to promoting enthusiastic and harmonious participation among them, it is for this reason, activities should be designed taking into account basic teaching strategies: observation, experimentation, oral and written expression, play and problem solving.

It is not enough to design and implement activities using the aforementioned strategies, it is necessary to work from the beginning on following the rules, motivating positive behaviors, questioning the interests of the students and making democratic agreements taking into account the opinion of all the students. In addition, to achieve an affective scenario it is necessary to show love, provide confidence and be understanding in any situation that arises, in this way the students will be able to visualize a friend, a confidant and a support

It is important to self-evaluate teaching practice to innovate the intervention itself and thus improve the quality of the education provided. And an important tool for this is the use of the Internet, which opens doors to search for ideas and enhance the creativity of each teacher. Therefore, after each intervention, it is important to assess and evaluate it to find alternatives for improvement, although the activities have been favorable, there is the possibility of improving or giving it another meaning to work with the same strategy in different training fields.

\section{Theoretical review (problem resolution)}

Create environments conducive to learning using teaching strategies such as experimentation, problem solving, observation, play, and oral and 
written expression. Provide preschool-level teachers with activities that help students develop skills, knowledge, values and principles, as well as abilities and skills, generating meaningful learning in them.

\section{Reflection}

The evaluation as an improvement of the teaching intervention for the generation of learning environments proposes the application of didactic strategies for the preschool level, where the development of competencies, knowledge and skills that enhance meaningful learning in students is encouraged. It is intended to provide teachers at this level with ideas to apply these strategies in curricular activities during a morning of work at any time during the school year.

Keywords: teaching strategies; learning environments; game.

Date Received: 05-08-2021
Date Acceptance:

11-10-2021
Date Publication:

05-11-2021 


\section{Referencias}

Duarte, J. (2003). Ambientes de aprendizaje. Una aproximación conceptual. Revista Iberoamericana de Educación, 33(1), 1-18, eISSN: 1681-5653. Recuperado de: https://doi.org/10.35362/rie3312961 Meneses, M., \& Monge, M. (2001). El juego en los niños: enfoque teórico. Educación, 25(2), 113-124, e-ISSN: 0379-7082. Recuperado de: https://www.redalyc.org/articulo.oa?id=44025210

Paredes, J., \& Sanabria, W. (2015). Ambientes de aprendizaje o ambientes educativos. "Una reflexión ineludible". Revista de Investigaciones, 15(25), 144-158, e-ISSN: 2539-5122. Recuperado de: http://dx.doi.org/10.22383/ri.v15i1.39

Meece, J. (2001). Desarrollo del niño y del adolescente: compendio para educadores. Primera reimpresión, ISBN: 970-18-4747-4. México: McGraw-Hill Interamericana.

Loyo, J., \& Toaquiza, A. (2016). Técnicas de animación infantil para niños/as del CIBV Ignacio Flores del cantón Latacunga. Proyecto de Investigación. Latacunga, Ecuador: Universidad Técnica de Cotopaxi.

Nanfro, L. (2016). Los videojuegos y el comportamiento social en jóvenes universitarios. Tesis de Licenciatura. Argentina: Universidad del Aconcagua.

Cardona, J. (2004). Diseño del plan de formación docente en estrategias didácticas para el aprendizaje significativo en la Institución Universitaria Salazar y Herrera. Medellín, Colombia: Universidad de Antioquia. 
PhD. Oscar Antonio Martínez Molina e-mail: oscar.martinez@unae.edu.ec

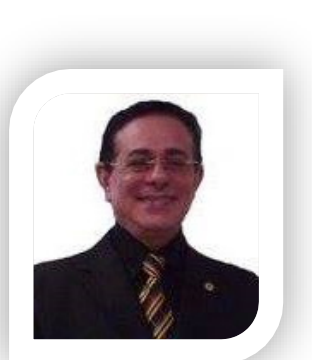

Nacido es San Cristóbal, estado Táchira, Venezuela, el 12 de octubre del año 1952. Residenciado en Cuenca, Ecuador. Licenciado en Educación Mención Orientación Educativa y Profesional por la Universidad de Los Andes (ULA), extensión Táchira, Venezuela; Magíster en Ciencias de la Educación Superior, Mención Andragogía por la Universidad Nacional Experimental de los Llanos Occidentales Ezequiel Zamora (UNELLEZ); Doctor en Educación Mención Suma Cum Laude de la Universidad de Málaga (UMA), España; Postdoctor en Estudios Libres de la Universidad Fermín Toro (UFT); Diplomado en Educación Abierta y a distancia por la Universidad Fermín Toro; Maestría de Experto Avanzado en E-learning por la Fundación para la Actualización Tecnológica de Latinoamérica (FATLA); Maestría de Experto en Tecnología Educativa nivel avanzado en la Fundación para la actualización tecnológica de Latinoamérica; Profesor Jubilado de la Universidad Nacional Abierta (UNA), Categoría Académica de Titular; Director de tesis doctorales y de maestría; Profesor investigador del Programa de Estímulo a la Innovación e Investigación en categoría "A-2"; Docente investigación de la Universidad Nacional de Educación (UNAE), Ecuador, Categoría principal 1; Coordinador del Grupo de Investigación GIET; Director Académico y de Operaciones de la Red Académica Internacional de Pedagogía e Investigación (RedINDTEC).

El contenido de este manuscrito se difunde bajo una Licencia de Creative Commons ReconocimientoNoComercial-Compartirlgual 4.0 Internacional 